\title{
SOCIAL SECURITY AMENDMENTS OF 1939: AN OBJECTIVE ANALYSIS*
}

\author{
Davm WaIDRON
}

\section{1}

HEE first four years of the Social Security Act witnessed an amazing change in the traditional thinking of America. As the several programs of social and economic welfare outlined in the statute swung into action, the average American found himself thinking in terms of new and strange concepts. He began to visualize insurance, for example, as a public enterprise in which he had a substantial stake, rather than as a private contract with an insurance company which only a

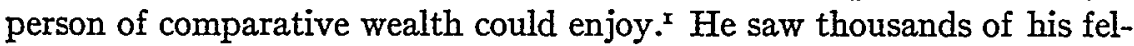

* All opinions expressed in this article are those of the author as an individual only. They are in no sense binding upon either the Federal Security Agency or the Office of the General Counsel to that agency.

$\dagger$ Attorney, Federal Security Agency.

Section numbers refer to the Social Security Act Amendments of 1939, unless otherwise indicated.

The word "board" as used herein means the Social Security Board.

"Tremendous as is the scope of this program, it was recognized from the beginning that changes would have to be made as experience and study indicated lines of revision and improvement. Congress, therefore, expressly provided in the Social Security Act that the Social Security Board should study and make recommendations as to methods of providing more effective economic security.

"Further to facilitate necessary revision, an Advisory Council on Social Security was created in May I937. It was composed of outstanding citizens representing employers, employees, and the public. The Advisory Council spent more than a year in study and deliberation and transmitted its final report and recommendations on December 10, 1938 .

"The recommendations of the Social Security Board, based upon 3 years of intensive study, were submitted to the President of the United States on December 30, 1938. The President transmitted the Board's report to Congress, with a special message on January 16, I939. The President's message and the Board's report were then referred to this committee." See H.R. Rep. 728, 76th Cong. Ist Sess., at 4 (r939).

The President of the United States, in transmitting the Report of the Social Security Board recommending changes in the Social Security Act, concluded his message to the Congress as follows:

"We shall make the most orderly progress if we look upon Social Security as a development toward a goal rather than a finished product. We shall make the most lasting progress if we recognize that Social Security can furnish only a base upon which each one of our citizens may build his individual security through his own individual efforts," President's message to Congress, H.R. Doc. Iro, 76 th Cong. Ist Sess. (1939).

I " . . . By June 1939 the Social Security Board had established 44.7 million employee accounts for workers throughout the United States. As of July 9, 1938 , wage items for the calendar year I937, amounting to $\$ 26.9$ billion, had been entered in 30.5 million individual 
low workers, caught in the "recession" of 1938 , drawing small but sure "unemployment compensation" benefits for several weeks following the loss of their jobs. ${ }^{2}$ He saw poorhouses disappear as the various forms of public assistance provided for in the new act took hold in the states. ${ }^{3}$

Although Congress had enacted a statute which was drafted in the light of the best information then available, real experience in actual operation

accounts. Preliminary estimates indicate that for the year 1938 , 29.6 million workers received $\$ 26.5$ billion in taxable wages.

"Since the beginning of the year $\mathrm{I} 937$, workers who have received wages from covered employment have been entitled to lump-sum payments on attaining age 65. Benefits have also been payable to the estates of workers who have died. As of June 30, 1939, the Social Security Board had certified to the Secretary of the Treasury a total of $38 \mathrm{r}, 700$ claims for these two types of lump-sum payments, amounting to $\$ 20.2$ million," 2 Social Security Bulletin 5 (August 1939).

2 "The first year of operation of the Social Security Act was marked by rapid strides in the enactment and approval of State unemployment compensation laws. Since the act specified as a condition of approval of these laws that 2 years must elapse between the date when employers were first liable for contribution to State funds and the first benefit payments, only 25 States were able to pay benefits before the end of the fiscal year r937-38. It is estimated that in May I938, I7.7 million workers had acquired wage credits under the laws of States then paying benefits; by July I939 all jurisdictions were paying benefits and, in all, there was an estimated total of 27.8 million workers with such wage credits.

"During the fiscal year 1937 -38, 17.9 million payments amounting to a total of \$180.0 million were made to unemployed workers under State unemployment compensation laws. The average payment in June $x_{93} 8$ amounted to $\$$ ro.65 a week for total unemployment and $\$ 5.3 \mathrm{I}$ a week for partial unemployment. During the fiscal year $1938-39,42.6$ million payments, amounting to $\$ 444.3$ million, were made. In June r 939 the average payment was $\$ 10.09$ a week for total unemployment and $\$ 5.53$ a week for partial unemployment," 2 Social Security Bulletin 4-5 (August r939).

3 "For old-age assistance the total obligations incurred for payments have increased from $\$ 243.2$ million in $1936-37$ to $\$ 4 \mathrm{II} .5$ million in $1938-39$. The number of individuals receiving aid has increased with the development of operations under this program. In June 1936 the number of recipients in 34 States was 603,700; for June 1939 the number was I.8 million in $5 \mathrm{I}$ States. (The term 'State' is used as defined in the Social Security Act to apply to the 48 States, the District of Columbia, Alaska, and Hawaii.) The average monthly payment to recipients in States with approved plans was \$15.99 in June r936 and \$19.42 in June r939.

"Total obligations incurred from Federal, State, and local funds for aid to dependent children amounted to $\$ 40.8$ million in $193^{6}-37$ and \$ro3.2 million in $193^{8-39}$. In June 1936 , 175 , 100 children in 69,700 families received payments under 20 approved State plans; in June I939, $7 \times 8,400$ children in 297,600 families received aid under 42 approved State plans. The average payment per family was $\$ 23.46$ in June 1936 and $\$ 3$ I.IO in June I939.

"For aid to the blind, total obligations for payments to recipients were $\$ 9.0$ million in I936-37 and SIx.9 million in $1938-39$. In June $x 936$ there were 17,600 recipients of aid to the blind in 21 States as compared with 44,500 recipients in 42 States in June 1939. Average monthly payments in the same months were \$24.xo in 1936 and $\$ 23.15$ in 1939 ," 2 Social Security Bulletin 4 (August 1939). 
over a period of time was necessary before anyone could say with finality how far the act had attained successfully its major objectives. This experience came in the years subsequent to August r4, I935 when the original Social Security Act was signed by the President. ${ }^{4}$ This experience was studied not only by the Social Security Board itself ${ }^{5}$ but also by the Advisory Council on Social Security which held meetings in the closing weeks of 1937 and throughout I938. These conferences culminated in the Advisory Council Report of December Io, I938. ${ }^{6}$

Thereafter Congress once more entered the picture more directly and after months of study, including public hearings before the Ways and Means Committee of the House and the Finance Committee of the Senate, a series of amendments was passed which were approved by the President on August I0, 1939.7

It is the purpose of this article to make an objective analysis of these amendments.

\section{TITLE I. OLD-AGE ASSISTANCE ${ }^{8}$}

Under the amendments, as heretofore, the Federal Government grants to each state having an approved public assistance plan an amount equivalent to one-half of its total expenditure for the needy aged. To this is added five percent of the federal grant which the state may use either for expenses of administration or for additional old-age assistance. The amending law increases the federal-state maximum to each individual from $\$ 30$ to $\$ 40$ per month. 9

Before certifying to the Secretary of the Treasury its estimate of the amount which will be paid to a state in any quarter, the board is required to determine and deduct the equivalent of the pro rata share to which the United States is equitably entitled in the net amount which a state or any political subdivision thereof has recovered during any prior quarter from the estates of persons who have received old-age assistance. The United States, for example, is equitably entitled to one-half of those amounts which the state recovers from the estates of those needy individuals to

${ }_{4}^{4} 9$ Stat. 620-48 (I935), 42 U.S.C.A. $\$ \S 301-1305$ (Supp. I938).

5 See Report of the Social Security Board to the President, H.R. Doc. x10, 76 th Cong. Ist Sess. (I939).

${ }^{6} \mathrm{~S}$. Doc. 4 , 76th Cong. Ist Sess. (1938).

7 H.R. 6635 Aug. Io, I939, C. 666, $\$$ IOI-60r (Pub. No. 379).

8 Title I of the original Social Security Act.

9 \& Ioz amending $\$ 3$ (a) of the Social Security Act. It is estimated that this change will cost the Federal Government from $\$ 5,000,000$ to $\$ 10,000,000$ per year, depending upon the extent to which the states take advantage of the new proposal. 
whom old-age assistance payments have been made; and to one-half of those amounts which have been paid by the state under mistake or fraud, and thereafter recovered..$^{\mathrm{x}}$

The Social Security Act, in those sections relating to payments to states and to the definition of aged individuals, has been amended by adding the word needy to the description of those aged individuals who seek to qualify for old-age assistance. ${ }^{\text {Ir }}$ This change was inserted in order to make all the sections of Title I uniform on the requirement of need. In this connection the amendments provide further that the plan submitted by a state to the board for approval must contain a provision that the state agency, in determining need, shall consider "any other income and resources of an individual claiming old-age assistance." ${ }_{12}$ The quoted language would seem broad enough to preclude, in determining need, any attempt to escape consideration of all types of income and resources, without regard to the nature thereof or to the source from which derived. ${ }^{\mathbf{3}}$

An approved old-age assistance plan must, as heretofore, set forth the state's proposed methods of administration, other than methods relating to selection, tenure of office, and compensation of personnel. After January I, I940, however, provisions of the state plan for methods of administration, although subject to the same exception, must include meth-

Io $\S$ I02 amending $\S 3$ (b) (2) of the Social Security Act. This change is in accordance with the recommendation of the board as follows:

"The Board recommends a number of minor technical changes to clarify and simplify existing Federal public assistance provisions: Of these the most important is provision for a different method of settlement with the States for amounts recovered from the estates of deceased recipients of old-age assistance. At present the States are not required to make collections against the estates of deceased recipients; nor does the Board propose that any such requirement be set up. However, a number of States do make such collections in accordance with their own plans. The present method of settlement between the States and the Federal Government in such cases creates needless administrative difficulties which can readily be eliminated by permitting the Federal Government to offset its pro rata share of the amounts recovered against the next payment made by it to the State," Report of the Social Security Board on Proposed Changes in the Social Security Act 27 (January 1939).

II $\S$ Ior and $\S$ IO3 amending $\S 3$ (a) and $\S 6$, respectively, of the Social Security Act.

$12 \S$ ror amending $\S 2$ (a) of the Social Security Act, effective July I, I94r.

${ }^{13}$ On the question of family support, institutional care and income as affecting "need" of applicants for old-age assistance, see Moore v. State Social Security Com'n, I22 S.W. (2d) 39 I (Mo. App. r938); Hubbell v. Ernst, 87 P. (2d) 985 (Wash. I939); State ex rel. Eckroth v. Borge, 283 N.W. 521 (N.D. 1939); Conant v. Washington, I97 Wash. 2x, 84 P. (2d) 378 (1938); Dean v. State Social Security Com'n, I23 S.W. (2d) 573 (Mo. App. 1939); Price v. State Social Security Com'n, 232 Mo. App. 72I, I2I S.W. (2d) 298 (I938). 
ods "relating to the establishment and maintenance of personnel standards on a merit basis." ${ }_{44}$

Under the amendments it is now mandatory that the plan provide for restriction of the use or disclosure of information concerning applicants and recipients to purposes directly connected with the administration of old-age assistance.15 This requirement is designed to insure efficient administration and to protect recipients from humiliation and exploitation.

TITLE II. FEDERAT OLD-AGE AND SURVIVORS INSURANCE BENEFITS ${ }^{16}$

FINANCING

The "Old-Age Reserve Account" created by the original act in the Treasury of the United States has been supplanted by the "Federal OldAge and Survivors Insurance Trust Fund." 17 This trust fund is set up in the treasury under a board of trustees consisting of the Secretary of the Treasury, the Secretary of Labor, and the Chairman of the Social Security Board, all acting ex officio as members. The Secretary of the Treasury is

34 \& Ior amending $\S 2$ (a) of the Social Security Act, effective January I, I940.

"The Board believes that requiring the State agencies to establish a merit system would place Federal-State relations on a more stable and automatic basis. In actual experience the result of establishing an adequate State personnel system has been to eliminate the necessity for detailed Federal scrutiny of operation, and the possibility of misunderstanding and conflict in Federal-State relations. The suggested requirement thus constitutes not an encroachment of Federal authority in State operations, but rather a protection to the States against undue interference with their administrative functioning.

"The establishment of a merit system also protects taxpayers and beneficiaries within the State, inasmuch as it materially reduces the hazard that administration will become so unsatisfactory that the State law can no longer be certified by the Board as meeting the administrative standards of the Federal act. Such inability to certify means that employers in a State would be required to pay to the Federal Government roo percent instead of ro percent of the Federal tax, in addition to paying their full tax under the State unemployment compensation law. Up to the present the Board has not found it necessary to withhold certification in the case of unemployment compensation, although it has been necessary to take such action regarding public assistance grants. Effective safeguards should be set up, in order to eliminate the possibility that the derelictions of their public servants may bring such a penalty upon innocent citizens of a State," Report of the Social Security Board on Proposed Changes 20 (January r939).

${ }_{25} \S$ Ior amending $\S 2$ (a) of the Social Security Act, effective July r, r94r.

${ }^{16}$ Amending Title II of the Social Security Act.

${ }_{77}$ For discussion of the Old-Age Reserve Account see Eliot, Funds for the Future, $\pi 62$ Atlantic Monthly 225 (Aug. I938), answered by Linton, Insuring the Future, I62 Atlantic Monthly 544 (Oct. I938). For a defense of the Old-Age Reserve Account see Willcox, Why the Old-Age Reserve Account Is Indispensable Apart from Tax Problems, 52 Annalist 237 (Aug. r7, 1938); Willcox, Social Security Taxation, Annual Appropriations and Anticipated Tax Receipts, 52 Annalist 27 (Aug. 24, I938); Willcox, Basic Policies under Social Security Act, Argument against System Analyzed, 52 Annalist 300 (Aug. 31, I938). 
designated "Managing Trustee." The Board of Trustees is required to report annually to the Congress and, under specified conditions, an immediate report must be made. ${ }^{x}$

The former method of making appropriations to the Old-Age Reserve Account as needed, and in accordance with accepted actuarial principles, has been changed by a provision which requires that the full amount of old-age insurance taxes collected shall be permanently appropriated to the trust fund.

The Secretary of the Treasury, as managing trustee, must invest in the trust fund all moneys which, in his judgment, are not needed to meet current withdrawals. He is no longer bound, however, to invest such funds in government obligations, "so as to provide an investment yield of not less than 3 per centum per annum," but, instead, he is required to invest in government obligations earning the current average rate of interest earned by all outstanding government obligations comprising the public debt. ${ }^{2}$

TYPES OF BENEFITS

It should first be noted in this connection that the payment of monthly insurance benefits is advanced from January I, I942, to January I, I940.20

Monthly primary insurance benefits, formerly termed federal old-age benefits, are payable on retirement after age sixty-five to those individuals who qualify. The amendments add two new provisions for payment of

${ }^{x} \& 201$ (b) (3):

"It shall be the duty of the Board of Trustees to ... .

"(3) Report immediately to the Congress whenever the Board of Trustees is of the opinion that during the ensuing five fiscal years the Trust Fund will exceed three times the highest annual expenditures anticipated during that five-fiscal-year period, and whenever the Board of Trustees is of the opinion that the amount of the Trust Fund is unduly small." The following is the recommendation of the Advisory Council with reference to the Old-Age Insurance Fund:

"At the time the Social Security Act was drafted it was deemed necessary for constitutional reasons to separate legally the taxation and benefit features of the program. It is believed that in the light of subsequent court decisions such legal separation is no longer necessary. Since the taxes levied are essentially contributions intended to finance the benefit program, it is not only logical but expedient to provide for automatic crediting of tax proceeds to the old-age insurance fund. It is believed by the Council that such a procedure would enhance public understanding of the contributory insurance system. Since the tax proceeds thus credited are intended for payment of benefits, it is recommended that they be deposited in a trust fund under the control of designaled trustees in accordance with appropriate legal provisions. The trust fund should be dedicated to the payment of benefits and, to a restricted amount, to the costs necessary to the administration of the program," Final Report of the Advisory Council on Social Security 49 (Dec. 10, 1938).

I9 See generally $\S$ 20r, which section provides for the Federal Old-Age and Survivors Insurance Trust Fund.

$20 \S 202$ (a). 
monthly benefits, (I) supplementary monthly benefits to wives and dependent children of individuals entitled to primary insurance benefits, ${ }^{2 x}$ and (2) monthly survivors benefits to widows and dependent children, or dependent parents, of properly qualified insured deceased individuals. ${ }^{22}$

Lump-sum payments formerly made upon attainment of age sixty-five to insured individuals who failed to qualify for monthly benefits are not provided for under the new law. In the absence of a provision in the amendments for payment of lump-sum benefits at age sixty-five, such payments ceased on the date the amendments were approved, August ro, I939. Lump-sum death payments made to estates or close relatives of a deceased insured individual in accordance with the provisions of the Social Security Act are provided for in the amendments only in cases where the deceased individual leaves no survivor entitled to monthly survivors benefits. ${ }^{23}$

In the interest of clarity and orderly presentation the meaning of the terms "fully insured individual" and "currently insured individual" is taken up before discussing the several types of benefits.

\section{"FULLY INSURED" AND "CURRENTLY INSURED"}

The terms "fully insured individual" and "currently insured individual" are not used in the original act. Under the amended act they signify the status of an insured individual. The basis of determination of status is a quarter of a calendar year, in which quarter the individual earned a minimum of $\$ 50$ while engaged in covered employment. Such calendar quarters are termed "quarters of coverage."

A "fully insured individual" is one who has engaged in covered employment for a sufficient period to accumulate quarters of coverage, the total of which equals half the number of calendar quarters after the year 1936 , or after he reaches his twenty-first birthday if later than the year 1936 , and before the quarter during which he attains the age of sixty-five or dies. Once he acquires forty quarters of coverage, the individual is fully insured, and it is not necessary that he engage in further employment to maintain his status. An individual who attains age sixty-five or dies after I936 and before he has six quarters of coverage is not fully insured. ${ }^{24}$

The benefits payable with respect to the wages of a fully insured individual include primary insurance benefits, supplementary insurance benefits, survivors insurance benefits, and lump-sum death benefits. ${ }^{25}$ The type of benefits payable is, of course, dependent upon the attendant circumstances of the particular case.

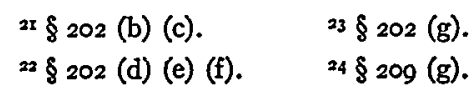

$25 \S 202$ (a) (b) (c) (d) (f) (g). 
A "currently insured individual" is defined as one who has been paid wages amounting to a minimum of $\$ 50$ in at least six quarters of coverage in the twelve calendar quarters preceding the quarter in which he died. ${ }^{26}$

The insurance benefits payable with respect to the wages of currently insured individuals are limited to three types, ( $\mathrm{I}$ ) survivors insurance benefits for dependent children, (2) survivors insurance benefits for widows with dependent children in their care, and (3) lump-sum death benefits payable in the event there is no survivor entitled to monthly benefits. ${ }^{27}$

\section{PRIMARY INSURANCE BENEFITS}

Primary insurance benefits are payable on retirement after attainment of age sixty-five to those individuals who qualify. Every individual who has reached the age of sixty-five years and who has applied for primary insurance benefits is entitled thereto after December 3I, I939, provided that he is a fully insured individual..$^{28}$

The computation of monthly benefits continues (as heretofore) to be directly related to the individual earnings of the worker.

Under the original Social Security Act the wage base used for determining the amount of benefits was total accumulated wages paid since December $3 \mathrm{x}$, I936. The amended law has changed the old base by substituting therefor the "average monthly wage" which is found by dividing the total wages in covered employment paid to an individual (before the quarter in which he died or became entitled to receive primary insurance benefits) by the total number of months he could have earned such wages, namely, three times the number of quarters which have elapsed after the year 1936 and before the quarter in which he became entitled to benefits or died. It is necessary, however, in computing the quarters to be divided into such aforementioned total wages, to exclude quarters in which the individual earned less than $\$ 50$ prior to attaining age twenty-two and quarters during the calendar years 1937 and 1938 if such quarters occurred after the individual had attained the age of sixtyfive. ${ }^{29}$ Under the formula provided in the original Social Security Act for computing benefits, namely, total accumulated wages paid, all the wages paid in covered employment after 1936 were included (except wages earned after age sixty-five) up to a maximum of $\$ 3,000$ a year from any one employer. The amended law provides (I) that any money over $\$ 3,000$ earned within one year, and before January I, I940, is not to be included in the meaning of the term "wages," regardless of the number of em-
$26 \S 209$ (h).
${ }^{27} \S 209$ (c) (e) (g).
$28 \& 202$ (a).
$29 \S 209$ (f). 
ployers; ${ }^{30}(2)$ service performed after age sixty-five and before January $I$, I939, is not to be included in the term "employment." "3x

The amount of monthly benefits, based upon the average monthly wage, is computed by adding (A) 40 percent of the average monthly wage if such wage does not exceed $\$ 50$ or, if in excess thereof, then 40 percent of $\$ 50$ plus Io percent of the amount in excess of $\$ 50$ but not to exceed $\$ 25^{\circ}$, plus (B) I percent of the basic amount (as computed under (A)) for each year in which the individual was paid $\$ 200$ or more of wages for services performed in covered employment. ${ }^{32}$

Changes have also been made in the requirements to be met in order to qualify for monthly old-age benefits. Attainment by the worker of the age of sixty-five continues to be a requirement. The old provisions prohibiting the worker from engaging in covered employment after retirement have been modified to permit him to do so on condition that his earnings do not exceed \$I5 per month. ${ }^{33}$ Finally, the new requirement that the worker must be a fully insured individual before be becomes entitled to monthly old-age benefits has supplanted the test applied in the original act. ${ }^{34}$

The minimum amount of monthly benefits, fixed at \$Io, remains the same as heretofore. ${ }^{35}$ The maximum amount of monthly benefits payable to a qualified individual was formerly fixed at $\$ 85$. The amendments, because of the provisions therein for the payment of monthly benefits to dependents and survivors, fix the maximum total monthly benefits payable to the individual upon retirement and to his dependents, or to survivors, in cases where the total for one month is more than $\$ 20$, at the

$30 \S 209$ (a) (I) (2). ${ }^{31} \S 209$ (b).

${ }^{32} \S 209$ (e). The increase of the basic amount of benefits (I percent of the basic amount for each year in which the individual was paid $\$ 200$ or more of wages for services performed in covered employment) is in the nature of an increment measured by length of employment.

$33 \S 203$ (d) (r).

$34 \S 210$ (c) of the original Social Security Act reads as follows:

"(c) The term 'qualified individual' means any individual with respect to whom it appears to the satisfaction of the Board that-

(x) He is at least sixty-five years of age; and

(2) The total amount of wages paid to him, with respect to employment after December $3 \mathrm{r}$, I936, and before he attained the age of sixty-five was not less than $\$ 2, \infty 00$; and

(3) Wages were paid to him, with respect to employment on some five days after December $3^{\mathrm{I}}, \mathrm{x}_{93} 6$, and before he attained the age of sixty-five each day being in a different calendar year."

$35 \S 209$ (e) (2). The minimum amount (\$ro) under the original act, was the quotient of one-half of I percent of the minimum amount of total wages $(\$ 2, \infty)$ required for an individual to qualify for monthly benefits. 
smallest of the following amounts: (r) twice the primary insurance benefit; (2) 80 percent of the average monthly wage of the individual; or (3) $\$ 85 \cdot^{36}$

Effective January I, I939, wages paid after age sixty-five may be included in computing benefits and are also taxable. ${ }^{37}$ Thus, in contrast to the old law, the new provisions enable the wage earner to increase the amount of benefits by continuing in covered employment after age sixtyfive.

\section{SUPPLEMENTARY BENEFITS}

Under the original act there was no provision for what are now termed supplementary benefits. These benefits are provided for wives of individuals entitled to primary insurance benefits and for their unmarried dependent children under eighteen years of age..$^{8}$ The right to obtain supplementary benefits is dependent upon specified conditions. ${ }^{39}$ The supplementary benefit of the wife is equal to one-half of the primary insurance benefit of her husband except that, if the wife is also entitled to a primary insurance benefit, her supplementary benefit, when added to her primary insurance benefit, must not be an amount greater than one-half of the primary insurance benefit of her husband. ${ }^{40}$ The supplementary benefit of a dependent child is equal to one-half of the primary benefit of its parent

$3^{36} \S 203$ (a). $\quad 37 \S 202$ (a). $\quad 3^{88} \S 202$ (b) (c).

39 § 202 (b) (I).

"Every wife (as defined in section 209 (i)) of an individual entitled to primary insurance benefits, if such wife (A) has attained the age of sixty-five, (B) has filed application for wife's insurance benefits, (C) was living with such individual at the time such application was filed, and (D) is not entitled to receive primary insurance benefits, or is entitled to receive primary insurance benefits each of which is less than one-half of a primary insurance benefit of her husband, shall be entitled to receive a wife's insurance benefit for each month, beginning with the month in which she becomes so entitled to such insurance benefits, and ending with the month immediately preceding the first month in which any of the following occurs: she dies, her husband dies, they are divorced a vinculo matrimonii, or she becomes entitled to receive a primary insurance benefit equal to or exceeding one-half of a primary insurance benefit of her husband.

"Every child (as defined in section 209 (k)) of an individual entitled to primary insurance benefits, or of an individual who died a fully or currentlyinsured individual (as defined in section 209 (g) and (h)) after December 3I, I939, if such child (A) has filed application for child's insurance benefits, $(B)$ at the time such application was filed was unmarried and had not attained the age of $I 8$, and (C) was dependent upon such individual at the time such application was filed, or, if such individual has died, was dependent upon such individual at the time of such individual's death, shall be entitled to receive a child's insurance benefit for each month beginning with the month in which such child becomes so entitled to such insurance benefits, and ending with the month immediately preceding the first month in which any of the following occurs: such child dies, marries, is adopted, or attains the age of eighteen," $\$ 202$ (c) (I).

$40 \S 202$ (b) (2). 
or, if more than one parent is entitled to primary benefits, the child's supplementary benefit is equal to one-half of whichever parent's primary insurance benefit is the greater..$^{4}$

\section{SURVIVORS MONTHIY BENEFIIS}

The original Social Security Act did not take into account monthly benefits for survivors of insured individuals. Benefits to survivors were limited to lump-sum death payments. The new law sets up a system, however, whereby monthly insurance benefits with respect to qualified individuals who die after December 3I, I939, are paid to widows, dependent children, or dependent parents who meet the stated requirements.

The widow of a fully insured individual, ( $I$ ) if she is aged sixty-five years, (2) has not remarried, (3) has applied for her insurance benefits, (4) was living with her husband when he died, and (5) is not entitled to a primary insurance benefit equal to or greater than three-fourths of that of her husband, is entitled to an amount equal to three-fourths of her husband's primary insurance benefit, providing that if she is receiving a primary insurance benefit, such amount shall be deducted from the payment made to her as a widow. The amount paid to her as a widow shall continue to be paid until she remarries, dies, or becomes entitled to receive a primary insurance benefit equal to or greater than that she received as her husband's widow. ${ }^{42}$

The widow of a fully or currently insured individual, having a dependent child in her care entitled to survivors benefits, is entitled to threefourths of her husband's benefit rate, provided she ( $I$ ) remains unmarried, (2) is not entitled to a survivors benefit as an aged widow (at least sixtyfive years of age), (3) was living with her husband at the time of his death, and (4) has applied for her insurance benefits. ${ }^{43}$

Each unmarried dependent child of an individual who dies fully or currently insured after December 3I, I939, for so long as he is under eighteen years of age, is entitled to monthly survivors benefits equal to one-half of the benefit rate of the deceased individual if such child was dependent upon him at the time of his death. ${ }^{44}$

Each aged dependent parent of a deceased, fully insured individual is entitled to monthly survivors benefits equal to one-half the primary insurance benefit rate of such deceased individual provided no widow and no unmarried child under eighteen survive. To qualify for survivors benefits it is necessary that the parent has attained the age of sixty-five years. It is mandatory also that the parent file proof (within two years after the
$45 \$ 202(c)(2)$.
$4^{2} \$ 202$
(d) (x) (2).
$43 \S 202(\mathrm{e})(\mathrm{I})(2)$.
4+ § 202 (c) (I). 
date of death) of complete dependency for support upon the deceased son or daughter. Furthermore, it must appear that the parent (I) is not entitled to receive any other survivors monthly benefits or "is entitled to receive one or more of such benefits for a month, but the total for such month is less than one-half of a primary insurance benefit of " the deceased individual; (2) has not remarried since such individual's death; and (3) has applied for benefits. ${ }^{45}$

The term "parent" includes both mother and father. It includes also a step-parent by a marriage contracted before the child, with respect to whose wages the claim is made, attained the age of sixteen. An adopting parent is a "parent" if such child was adopted before attaining the age of sixteen..$^{6}$

\section{IUMP-SUM DEATH BENEFITS}

Death benefits in a lump sum equal to $3 \frac{1}{2}$ percent of the total accumulated wages credited subsequent to December $3 \mathrm{I}, \mathrm{I} 936$, to an individual who dies before January I, I940, will be paid, as heretofore, to his relatives or to his estate. The new law provides that after January $\mathrm{I}$, I940, lump-sum death benefits shall be paid only when the insured individual leaves no survivor entitled to survivors benefits and, in that event, in an amount equal to six times the monthly primary insurance benefit. The payment is made to surviving relatives named in the statute or, if no such relatives survive, then to any person or persons "to the extent and in proportion that he or they shall have paid the expenses of burial of the deceased." Claim must be made for lump-sum death benefits by those entitled thereto within two years after the death of the insured individual. ${ }^{47}$

\section{DEDUCTIONS FROM BENEFITS}

The new law imposes the duty upon the board to make deductions from payments under Title II up to the full amount of the individual's monthly benefit or benefits for any month after retirement in which he rendered services for wages totaling \$ 5 or more. In like manner violation of the retirement provision by an individual with respect to whose wages a benefit or benefits are payable also renders a wife's or child's insurance benefit subject to deduction. Similarly deductions must be made (I) if a child under eighteen and over sixteen years of age failed for any month to attend school regularly and the board finds that attendance was feasible, or (2) if for any month "a widow entitled to a widow's current insurance benefit did not have in her care a child of her deceased husband entitled to receive a child's insurance benefit." ${ }^{48}$
$45 \S 202$ (f) (I) (2).
$47 \S 202(\mathrm{~g})$.
${ }^{46} \S 202$ (f) (3).
$4^{8} \S 202(\mathrm{~d})(\mathrm{I})(2)(3) ; \S 202(\mathrm{e})$. 
THE TERM "EMPLOYMENT"

The term "employment" is defined in the original Social Security Act as "any service, of whatever nature, performed within the United States by an employee for his employer." This definition was intended to be interpreted, subject to the exceptions, as employment generally in industry and commerce..$^{9}$ The amendments have expanded the meaning of the term to include services by an employee for the person employing him, irrespective of the citizenship or residence of either, performed within the United States or performed in maritime service on American vessels. ${ }^{50}$ Only maritime service performed on foreign vessels and service performed on certain fishing vessels of less than ten tons are excepted under the provisions of Title II. . $^{\mathrm{I}}$

Employment coverage has also been extended by modification of some of the former exceptions..$^{52}$ The former exemption of service performed in the employ of federal, state, or local governments or their instrumentalities has been revised to exclude from the exemption service in the employ of federal, state, or local instrumentalities which are either not wholly owned by the employer or are not exempted from state taxation by the Federal Insurance Contributions Act or United States Constitution or are not exempted from federal taxation by any provision of law. ${ }^{53}$

A further important enlargement of coverage results from the removal

49 The exceptions to employment under the original act were as follows:

"(I) Agricultural labor;

(2) Domestic service in a private home;

(3) Casual labor not in the course of the employer's trade or business;

(4) Service performed as an officer or member of the crew of a vessel documented under the laws of the United States or of any foreign country;

(5) Service performed in the employ of the United States Government or of an instrumentality of the United States;

(6) Service performed in the employ of a State, a political subdivision thereof, or an instrumentality of one or more States or political subdivisions;

(7) Service performed in the employ of a corporation, community chest, fund, or foundation, organized and operated exclusively for religious, charitable, scientific, literary, or educational purposes, or for the prevention of cruelty to children or animals, no part of the net earnings of which inures to the benefit of any private shareholder or individual," $\S 210(\mathrm{~b})(\mathrm{I})-(7)$.

so $\S 209$ (b), effective December 3I, I939.

${ }^{51} \S 209$ (b) (5); $\S 209$ (b) (I4). Service on vessels in connection with the catching or taking of salmon or halibut for commercial purposes are not excepted even though performed on a vessel of less than ten net tons. See $\$ 2$ IO (b) (I4) (A).

52 Exceptions which have not been changed or added by the amendments are not discussed.

$53 \S 209$ (b) (6) (7). The effect of this change is to include services performed in employment for banks, building and loan associations, savings and loan associations, and certain other organizations of like nature. 
of the "stoppage date" at age sixty-five. Such services as are covered prior to attainment of age sixty-five will be included as covered employment after January $x, r_{939}$, when performed by persons after attainment of age sixty-five and before retirement. ${ }^{54}$

On the other hand, the original exceptions relative to agricultural labor and domestic service have been amended to extend exemption to certain services in connection therewith which were not previously exempt.55

The domestic service exemption has been re-defined to include service in a local college club, fraternity, or sorority, in addition to the former exception of domestic service in a private home.

The new definition of "agricultural labor" is designed to clarify the meaning of this term and to extend the exemption to certain services which, though not previously excepted, are closely related to farming activities. These additional specific agricultural labor exemptions were provided for as the result of experience in determining coverage under the general definition of such service in the original act. The term "agricultural labor" is defined in the amendments to include:

(I) Service of a purely agricultural nature performed on a farm regardless of whether the employer is the owner or tenant of the farm. ${ }^{.6}$

(2) Certain service performed in the employ of the owner or tenant or other operator of a farm, provided the major part of such service is performed on a farm. This type of service includes service "in connection with the operation, management, conservation, improvement, or main-

$54 \S 209$ (b). It is estimated that the inclusion of maritime service on American vessels together with service performed after age sixty-five and service performed for certain government instrumentalities will add about $I, 100,000$ additional workers to the total of covered employees.

ss Relative to inclusion of agricultural labor and domestic service, the Advisory Council recommended that:

"The coverage of farm employees and domestic employees under titles III and VIII is socially desirable and should take effect, if administratively possible, by January I, r940," Final Report of the Advisory Council on Social Security 39 (December Io, I938).

The Social Security Board also recommended that the agricultural labor and domestic service exemptions be eliminated entirely "with a reasonable time allowed before the effective date," Report of the Social Security Board on Proposed Changes 9 (January, r939). On the contrary, the amendments, as enacted, broadened these two exceptions.

$56 \S 209$ (l) (x).

"As used in this subsection, the term 'farm' includes stock, dairy, poultry, fruit, fur-bearing animal, and truck farms, plantations, ranches, nurseries, ranges, greenhouses or other similar structures used primarily for the raising of agricultural or horticultural commodities, and orchards," § 209 (l) (x). 
tenance of the farm and its tools and equipment, or in salvaging timber or clearing land of brush and other debris left by a hurricane." 57

(3) Service performed (whether or not performed on a farm or for an owner or tenant thereof) in connection with the production or harvesting of maple sirup or maple sugar or any commodity defined as an agricultural commodity in Section 55 (g) of the Agricultural Marketing Act. ${ }^{88}$ Exemption under this subsection also includes other services which are construed to be closely connected with agricultural pursuits, namely, the raising or harvesting of mushrooms, the hatching of poultry, the ginning of cotton and the operation or maintenance of ditches, canals, reservoirs, or waterways used exclusively for supplying or storing water for farming purposes.

(4) Service performed (whether or not performed on a farm or for an owner or tenant thereof) in connection with any agricultural or horticultural commodity, if performed "as an incident to ordinary farming operations," that is to say, incident to the preparation for market of such commodities, in their unmanufactured state, by employees of farmers or of members of farmers' cooperatives who have themselves produced the commodity in connection with which the service is performed. This exemption also applies to service performed as an incident to the preparation of fruits and vegetables for market whether or not such service is performed as an incident to ordinary farming operations and irrespective of whether performed in the employ of the actual producer. ${ }^{59}$

The definition of employment is further limited by the addition of new exceptions: ( $I$ ) service performed in the employ of a foreign government; (2) service performed in the employ of an instrumentality wholly owned by a foreign government (under specified conditions); $;^{60}$ (3) service per-

$57 \S 209$ (1) (2). Included among persons who perform services of this nature are carpenters, painters, farm supervisors, general repairmen, irrigation engineers, etc., and such services are excepted so long as they are not performed in the employ of a third person or concern contracting with the owner, tenant, or operator of the farm to do the work.

$5^{8} \S 209$ (l) (3). $\S r_{5}(\mathrm{~g})$ of the Agricultural Marketing Act is as follows:

"Agricultural commodity definition. As used in this subchapter, the term 'agricultural commodity' includes, in addition to other agricultural commodities, crude gum (oleoresin) from a living tree, and the following products as processed by the original producer of the crude gum (oleoresin) from which derived: gum spirits of turpentine and gum rosin, as defined in section 92 of Title $7, " 46$ Stat. I8 (I929), 46 Stat. I550 (I93r), I2 U.S.C.A. § II4Ij (I936). March 4, I93I, C 520.

$59 \$ 209$ (l) (4).

$60 \$ 209$ (b) (12). The conditions under which services are excepted are:

"(A) If the service is of a character similar to that performed in foreign countries by employees of the United States Government or of an instrumentality thereof; and

"(B) If the Secretary of State shall certify to the Secretary of the Treasury that the foreign government, with respect to whose instrumentality and employees thereof exemption is 
formed for nominal remuneration in the employ of voluntary fraternal and beneficial associations or other non-profit institutions exempt from income $\operatorname{tax}^{6 \mathrm{x}}$ and service performed for a nominal consideration in the employ of an organization exempt from income tax by an enrolled student regularly attending classes at a school, college, or university; (4) service performed in the employ of hospitals by internes and nurses in training; (5) service performed in family employment for a son, daughter, or spouse; or for a parent if the employee is under the age of twenty-one years; (6) service performed by newsboys under eighteen years of age in the delivery or distribution of newspapers or shopping news where no re-delivery or redistribution is made; (7) service performed in the employ of an agricultural or horticultural organization exempt from income tax; (8) service in the employ of voluntary employees' beneficiary associations (under specified conditions) ${ }_{2}^{62}$ (9) service in the employ of a school, college, or university not exempt from income tax at which the employee is an enrolled student regularly attending classes provided the remuneration for such service does not exceed $\$ 45$ per quarter (exclusive of room, board, and tuition); and (Io) service performed by an individual as an employee or employee representative as defined in Section I532 of the Internal Revenue Code. ${ }^{63}$

claimed, grants an equivalent exemption with respect to similar service performed in the foreign country by employees of the United States Government and of instrumentalities thereof;"

$6 x \$ 209$ (b) (IO) (A). In order to eliminate the nuisance of inconsequential tax payments the act excludes certain services performed for fraternal benefit societies and other non-profit institutions exempt from income tax, and certain other groups. While the earnings of a substantial number of persons are excluded by this subsection, the total amount of earnings involved is undoubtedly very small. No estimate is available of the number of persons or amount of earnings so excluded. The intent of the amendment is to exclude those persons and those organizations in which the employment is part-time or intermittent and the total amount of earnings is only nominal, and the payment of the tax is inconsequential and a nuisance. The benefit rights built up are also inconsequential. Many of those affected, such as students and the secretaries of lodges, will have other employment which will enable them to develop insurance benefits. This amendment, therefore, should simplify the administration for the worker, the employer, and the Government. See S. Rep. 734, 76th Cong., Ist Sess., at I9 (1939).

62 'Service performed in the employ of a voluntary employees' beneficiary association providing for the payment of life, sick, accident, or other benefits to the members of such association or their dependents or their designated beneficiaries, if (i) admission to membership in such association is limited to individuals who are officers or employees of the United States Government, and (ii) no part of the net earnings of such association inures (other than through such payments) to the benefit of any private shareholder or individual," $\S 209$ (b) (ro) (D).

${ }^{63} \S I_{532}$ (c) of the Internal Revenue Code is as follows:

"The term 'employee representative' means any officer or official representative of a railway labor organization other than a labor organization included in the term 'employer' as defined in subsection (a), who before or after June 29, 1937, was in the service of an employer as defined in subsection (a) and who is duly authorized and designated to represent employees in accordance with the Railway Labor Act, 44 Stat. 577, U.S.C., Title 45, c. I8 [sic; 8?], as amended, and any individual who is regularly assigned to or regularly employed by such officer or official representative in connection with the duties of his office." 
It should be noted also that the old exemption of services in the employ of religious, charitable, scientific, literary, or educational organizations which required (I) that such organizations be organized and operated for certain purposes and (2) that no part of the net earnings inure to the benefit of any private shareholder or individual, has been enlarged by adding the additional qualification that no substantial part of the activities of such organizations shall be the carrying on of propaganda, or otherwise attempting to influence legislation. The change brings this exemption into conformity with the corresponding exemption from income tax under Section Ior(6) of the Internal Revenue Code. ${ }^{64}$

\section{INCLUDED AND EXCLUDED SERVICES}

The new definition of included and excluded services (added by the amendments) relates to those situations where an employee performs services both in excepted and covered employment for the same person in any pay period of not more than thirty-one consecutive days..$^{65}$ For example, an employee may perform service for the same person during such a pay period both in excepted employment as a farm hand engaged in harvesting crops and in covered employment as a machinist engaged in a commercial enterprise. The definition makes it clear that the predominant service (one-half or more) shall control to determine coverage during that period. The troublesome task of determining the period of covered employment and of allocating taxable wages for covered services is thus avoided. ${ }^{66}$

\section{TITLE III. GRANTS TO STATES FOR UNEMPLOYMIENT COMIPENSATION ADMINISTRATION ${ }^{67}$}

The amendments provide for additional provisions to be included in state unemployment compensation laws before certification of federal grants for unemployment compensation administration shall be made by the Board.

${ }^{64}$ As to exceptions to employment under the amendments, see generally $\S 209$ (b).

$65 \S 209$ (c).

${ }^{66}$ In addition to the administrative change made with respect to furnishing a statement containing certain data as to wages, etc., by an employer to an employee (discussed at page I05 infra) the following important administrative changes have been made by Title II of the amendments: ( $\mathrm{I}$ ) a provision for making more equitable the recovery by the Federal Government of incorrect payment to individuals ( $\$ 204$ (a) (b) (c)); (2) a provision respecting the practice of attorneys and agents before the board $(\$ 206) ;(3)$ detailed provisions relating to rules and regulations, hearings and decisions with respect to insurance benefits, procedure for judicial review of the board's decisions, and delegation of authority by the board ( $\$ 205)$; and (4) provision for giving an opportunity for a hearing to a wage earner or interested individual with respect to any entry, omission, or revision of the board's wage record within four years after the year any wages were paid or alleged to have been paid, as to the finality of the record ( $\$ 205$ (c) (2)). See S. Rep. 734, 76th Cong., Ist Sess., at 20-2I (1939).

${ }_{7}$ Title III of the original Social Security Act. 
The amendments require that the board must be satisfied with the following provisions of the state law: (I) there must be a provision which limits the expenditure of federal funds for the administration of the state law to only such purposes and in only such amounts as the board deems necessary for proper and efficient administration $;^{68}(2)$ in addition to the provision, formcrly required, for the immediate payment to the Secretary of the Treasury of all money received in the state's unemployment fund, there must be a provision for the reduction from this payment to the Secretary of the Treasury of refunds paid by the state both on account of erroneous payments into the fund, and in accordance with the provisions of Section 1606 (b) of the Federal Unemployment Tax Act; ${ }^{69}$ (3) the requirement in the state law that all money which the state withdraws from its unemployment fund must be expended in the payment of unemployment compensation, exclusive of administration expenses, has been modified by excluding from such necessary expenditure all refunds made of sums erroneously paid and all refunds paid to instrumentalities of the United States or its employees in accordance with Section I606 (b) of the Federal Unemployment Tax Act; $;^{70}$ (4) should the state lose any of the money granted for the administration of its unemployment compensation law, or spend the whole or any part of it for purposes other than that of administration, or spend more than the board finds necessary in the proper administration of the state law, provision must be made in the state law for replacement of such funds by the state within a reasonable time $;^{7 \mathrm{I}}$ and (5) after January I, I940, the state law must provide for the establishment and maintenance of personnel standards (other than selection, tenure of office, and compensation) on a merit basis, which are reasonably calculated to insure "full payment of unemployment compensation when due."'72

TITLE IV. GRANTS TO STATES FOR AID TO DEPENDENT CHILDREN ${ }^{73}$

Effective January I, r940, federal matching grants for aid to dependent children are increased from one-third to one-half of the total amount

68 $\S 302$ adding subsection (8) to $\S 303$ (a) of the Social Security Act.

${ }^{69} \S 3^{02}$ amending $\S 303$ (a) (4) of the Social Security Act. $\S 1606$ (b) of the Federal Unemployment Tax Act, which empowers a state to require certain instrumentalities of the United States, and the individuals in their employ, to make contributions to the state unemployment fund under the state law, conditions such power, inter alia, upon the state law containing a provision for the refund of any such contributions for any year in which the state is not certified by the board with respect to such year.

$70 \$ 302$ amending $\$ 303$ (a) (5) of the Social Security Act.

${ }^{\pi} \$ 302$ adding subsection (9) to $\$ 303$ (a) of the Social Security Act.

$72 \$ 302$ amending $\$ 303$ (a) (r) of the Social Security Act.

${ }^{\text {is }}$ Title IV of the original Social Security $A$ tct. 
expended by the state for assistance and administration, ${ }^{74}$ not counting so much of such expenditure as exceeds the monthly maximum amount per child established by the original Social Security Act. ${ }^{75}$ The state is authorized, as formerly, to expend federal grants for aid to dependent children up to the age of sixteen years and, under the amended law after January I, I940, up to the age of eighteen years if they are regularly attending school..$^{6}$ In addition to the age requirements necessary to qualify as a "dependent child" it is now specifically provided that the child must be "needy" to be dependent.77

Prior to a given quarter the state must file a report with the board in order to enable the board to estimate the amount to be paid to the state for that quarter. If the report discloses that the amount appropriated or made available by the state is less than one-half (formerly two-thirds) of the estimated expenditures, the report must set forth the source or sources from which the state expects to derive the difference..$^{8}$

Prior to the beginning of each quarter, the board must certify to the Secretary of the Treasury the estimated amount to be paid to a state for aid to dependent children. Before such certification is made, however, the board must make such adjustments of its estimates as are found necessary to insure to the Federal Government its pro rata share of any amount recovered by the state from recipients. ${ }^{79}$

\section{TITLE V. AMENDMENTS TO TITLES V AND VI OF THE SOCIAL SECURITY ACT}

Title V of the original Social Security Act dealt with grants to states for maternal and child welfare and vocational rehabilitation. The provisions of Title VI of the Social Security Act had to do with public health. Amendments affecting all of these public welfare services are grouped under Title $\mathrm{V}$ of the amendments of 1939.

$74 \S 402$ (a) amending $\S 403$ (a) of the Social Security Act, effective January I, I940.

75 The maximum amount per child established by the original Social Security Act is \$I8 per month for the first dependent child, and if there is more than one dependent child in the same home, $\$ 12$ per month for each additional dependent child. $\$ 403$ (a) of the Social Security Act.

${ }^{76} \S 403$ amending $\S 406$ (a) of the Social Security Act.

$77 \S 403$ amending $\S 406$ (a) of the Social Security Act. After July I, I941, the state in determining need must consider any other income and resources of any child applying for aid under Title IV. Further, $\$ 401$ (b) amending $\S 402$ (a) of the Social Security Act requires the state to provide safeguards which restrict the use and disclosure of information concerning applicants and recipients under the provisions of Title IV to purposes directly connected with the administration thereof. It is also provided by $\S 40 \mathrm{O}$ (a) (amending $\S 402$ (a), of the Social Security Act) that, after January I, 1940, the state plan must provide for methods relating to the establishment and maintenance of personnel standards on a merit basis.

${ }^{8} \S 402$ (a) amending $\S 402$ (b) (x) of the Social Security Act.

$79 \S 402$ (b) amending $\S 403$ (b) (2) of the Social Security Act. 
The principal amendments to Titles V and VI of the Social Security Act provide for increased appropriations for yearly grants to states, ${ }^{80}$ as follows:

\section{YzarLy Appropriation}

\begin{tabular}{|c|c|c|}
\hline & $\begin{array}{l}\text { Under the Original } \\
\text { Social Security Act }\end{array}$ & $\begin{array}{l}\text { Under the } \\
\text { Amendments }\end{array}$ \\
\hline aternal and child health services. & $\$ 3,800, \infty$ & $\$ 5,820, \infty 00$ \\
\hline Services for crippled children...... & $2,850, \infty 00$ & $3,870, \infty 00$ \\
\hline Child welfare services.. & $1,500, \infty 00$ & $I, 510, \infty 00$ \\
\hline Vocational rehabilitation & $1,938,000$ & $3,500,000$ \\
\hline Public health. . & $8,000, \infty 00$ & II $, \infty \infty, \infty 00$ \\
\hline
\end{tabular}

The only new provision required to be included in the state ${ }^{8 \mathrm{r}}$ plan for maternal and child services and for services for crippled children is for methods relating to the establishment and maintenarice of personnel standards on a merit basis. ${ }^{82}$

${ }^{80}$ From the amount appropriated for yearly grants to states for maternal and child health services, in addition to the prescribed yearly allotment of $\$ 20,000$ to each state, the Secretary of Labor must allot to each state for each fiscal year (a) such part of the sum of $\$ 2,800,000$ (formerly $\$ r, 8 \infty, \infty)$ ) as "he finds that the number of live births in such state bore to the total number of births in the United States" ( $\$ 502$ (a) amending $\S 502$ (a) of the Social Security Act); and (b) the sum of $\$ r, 980,000$ (formerly $\$ 980,000$ ) "according to the financial need of each state for assistance in carrying out its state plan, as determined by him after taking into consideration the number of live births in such state." $\$ 502$ (b) amending $\S 502$ (b) of the Social Security Act.

By similar provisions in the amendments the Secretary of Labor is required to allot to the states for each fiscal year, from the yearly appropriation for yearly grants to the states for services for crippled children, the specified sum of $\$ 2,830,000$ (formerly the "remainder" after the prescribed yearly allotment of $\$ 20,000$ to each state) "according to the financial need of each state as determined by him after taking into consideration the number of crippled children in each state in need of the services and the cost of furnishing such services to them." $\$ 505$ (a) (b) amending $\S 512$ (a) of the Social Security Act.

Of the sums appropriated by the United States to be allotted each fiscal year for the purpose of strengthening programs for vocational rehabilitation of the physically disabled, the amount to be allotted to the Territory of Hawaii has been increased from $\$ 5,000$ to $\$ 15,000$. The remainder of the appropriation continues to be apportioned among the several states with the requirement, however, that the amount allotted to any state for any fiscal year shall not be less than $\$ 20,000 . \S 508$ (a) amending $\S 53$ I (a) (2) (3) of the Social Security Act.

The amount to be appropriated each fiscal year for the purpose of administering the Vocational Rehabilitation Act of June 2, I920, as amended (4I Stat. 735 (I920), 29 U.S.C.A. § $3 \mathrm{I}$ (I927); 47 Stat. 448 (I932), 29 U.S.C.A. \& 3 I (Supp. I938); 47 Stat. 449 (r932), 29 U.S.C.A. § 32, 34 (Supp. 1938); 46 Stat. 525 (r930), 29 U.S.C.A. 35 (Supp. r938); 47 Stat. 450 (I932), 29 U.S.C.A. $\S 37,39$ (Supp. 1938 ); 46 Stat. 526 (I930), 29 U.S.C.A. $\S 40$ (I927)) has been increased from $\$$ I02,000 to $\$ 150,000$. $\S 508$ (a) amending $\S 53$ I (b) of the Social Security Act.

8I $\S 80$ r amending $\S$ rror (a) ( $x$ ) of the Social Security Act.

82 Effective January $\mathrm{I}, 1940$, the definition of the term "state," when used in Titles V and VI of the amended Social Security Act, has been amended to include Puerto Rico. $\$ \S 503$ and 506 amending respectively $\$ \S 503$ (a) (3) and 5 I3 (a) (3) of the Social Security Act. 


\section{TITIE VI. AMENDMENTS TO THE INTERNAI REVENUE CODE ${ }^{83}$}

\section{FEDERAL INSURANCE CONTRIBUTIONS ACT $^{84}$}

On April I, I939, Subchapter A of Chapter 9 of the Internal Revenue Code, which levies old-age insurance taxes upon employers of one or more and upon their employees, superseded Title VIII of the Social Security Act. Subchapter A, now known as the Federal Insurance Contributions Act, was amended by the Social Security Act Amendments of 1939 .

I. Tax base.-The federal old-age insurance tax, based upon the wages of every individual engaged in covered employment, ${ }^{85}$ is levied, collected, and paid in addition to all other taxes upon his income.

An important amendment changes the rate of the tax, which is imposed alike upon employer and employee, by continuing the I percent rate through the calendar years I940, I94I, and 1942 on wages received by the worker after December 31 , $1936,{ }^{86}$ thus repealing the former $1 \frac{1}{2}$ percent rate for those years. The 2 percent tax rate for the calendar years 1943 , I944, and 1945 , and the $2 \frac{1}{2}$ percent rate for the years 1946 , I947, and 1948 remain unchanged. As under the former law, a rate of 3 percent is imposed after December 3 I, I948. ${ }^{87}$

The amended act continues the wage base for determining the amount of the tax as total wages received excepting, of course, wages in excess of the stipulated yearly maximum of $\$ 3,000$ paid to any one employee. ${ }^{88}$

${ }^{8}{ }_{3}$ Formerly Titles VIII and IX of the original Social Security Act, now H.R. 2762, Feb. ro, 1939 (Pub. No. r).

84 Formerly Title VIII of the original Social Security Act.

${ }^{85}$ Changes made under Subchapter A of Chapter 9 of the Internal Revenue Code with respect to coverage of services rendered in employment are the same as the changes made in connection with such services under TitleII of the amendments. The new definition of included and excluded services under Subchapter A, Chapter 9 of the Internal Revenue Code is identical with the definition of such services under Title $\amalg$ of the amendments. $\S 606$, and $\S I 426$ (c) of the Internal Revenue Code.

${ }^{86}$ Under the Social Security Act as originally drafted, the I percent rate was scheduled to end on December 35, I939.

$87 \S \S 60 \mathrm{r}$ and 604 amending respectively sections I400 and r4IO of the Internal Revenue Code. With reference to the extension of the I percent rate the Advisory Council recommended that:

"The consideration of change in the tax schedule under Title VIII of the law should be postponed until after the rates of $x \frac{1}{2}$ percent each on employer and employee are in effect since information will not be available for some time concerning (a) tax collections under varying conditions, (b) effective coverage under taxes and benefits, (c) average covered earnings, period of coverage, time of retirement, and average amount of benefits, (d) the possibilities of covering farm labor, domestic employees or self-employed persons, and (e) the possibilities of introducing new types of benefits," Final Report of the Advisory Council on Social Security 48 (December ro, I938).

$88 \S 606$ and $\delta 1426$ (a) (I) of the Internal Revenue Code. 
The formula for computing the amount of the tax also has been changed. Before the amendments, the tax was levied on wages paid with respect to employment during any calendar year at the rate in effect during the calendar year when such services were performed. Under the amended act, however, the rate of tax is the rate applicable for the period during which the wages are received, regardless of the time when the services were performed. ${ }^{89}$ Thus it becomes apparent that the application of the new formula will greatly minimize those instances where refunds for overpayment and reassessment for underpayment previously were necessary.

2. Adjustments. - In cases where the employer either overpaid or underpaid the employee's tax, adjustments were made by the employer, under the original act, "in connection with subsequent wage payments to the same individual by the same employer." The amending act, recognizing the uncertainty of continued employment, simply provides that adjustments shall be made "with respect to any payment of remuneration" in accordance with authorized regulations. ${ }^{\circ 0}$

3. Special refund to employees and receipts for employees.-A new provision has been added allowing a "special refund" to an employee who has more than one employer during a particular calendar year. Each employer of a particular employee must pay both the employer's and employee's tax on wages up to $\$ 3,000$ paid to and received by the employee in a particular year, irrespective of the number of employers involved.

The employee, however, with respect to whose wages the deductions have been made and the taxes paid is entitled to a refund, without interest, of all such deductions on wages received in excess of $\$ 3, \infty$ paid to him in a particular year, regardless of the number of employers from whom he has received the total in excess of $\$ 3,000$. The employee must make claim for such refund after the calendar year in which the employment was performed and with respect to which the refund of tax is claimed. A limitation of two years after the calendar year in which the wages are paid is placed upon the right of the employee to assert his claim. ${ }^{\text {I }}$

4. Wages.-Although the tax base remains the same, i.e., the first $\$ 3,000$ of wages received by an employee from an employer, the amendments have specifically excluded certain payments from the definition of wages. The exclusions are: (I) payment to or on behalf of an employee under any employer plan or system providing for (a) retirement benefits,

\footnotetext{
$89 \$ 604$ amending $\$$ x4IO of the Internal Revenue Code. Code.

${ }^{90} \S \S 602$ (a) and 605 amending respectively $\S \S \mathrm{I} 40 \mathrm{I}$ (c) and $\mathrm{r} 4 \mathrm{II}$ of the Internal Revenue
}

9x $\S 602$ (b) adding subsection (d) to $\S \mathrm{I} 40 \mathrm{I}$ of the Internal Revenue Code. 
or (b) sickness or accident disability benefits, or (c) medical and hospitalization expenses in connection with sickness or accident disability, or (d) payments on account of death. ${ }^{92}$ These exclusions comprehend premium payments made by an employer for insurance or annuities, or payments into a fund to provide for any such insurance payments, or to establish such a fund; (2) payment by an employer (without deduction from the employee's wages) of an employee's old-age insurance tax; (3) employee's contributions under a state unemployment insurance law; and (4) dismissal payments by an employer which are not required by law.93

5. Statements to employees. - A new duty has been placed upon the employer to furnish each employee with a written form or statement showing the wages paid by him to the employee during specified periods. The statement must also show the names of the employer and employee, the period covered by the statement, and the amount of the tax imposed with respect to wages paid. ${ }^{94}$

\section{FEDERAL UNEMPLOXMENT TAX ACT 95}

I. Tax base.-The wage base for determining the amount of employers' unemployment compensation tax has been changed from total wages "payable" to total wages "paid," except wages in excess of $\$ 3, \infty 00$ per year paid to any one employee..$^{96}$ The effect of these amendments is to make

92 Death benefit payments made under such plan or system (including life insurance) are excluded only provided the employee "(i) has not the option to receive, instead of provision for such death benefit, any part of such payment or, if such death benefit is insured, any part of the premiums (or contributions to premiums) paid by his employer, and (ii) has not the right, under the provisions of the plan or system or policy of insurance providing for such death benefit, to assign such benefit, or to receive a cash consideration in lieu of such benefit either upon his withdrawal from the plan or system providing for such benefit or upon termination of such plan or system or policy of insurance or of his employment with such employer," $§ 606$ adding subsection (2) to $\$ 1426$ (a) of the Internal Revenue Code.

93 See generally $\S 606$ amending $\S 1426$ (a) of the Internal Revenue Code.

$94 \S 603$ adding $\S$ I403 to the Internal Revenue Code, effective January I, I940. This provision is an important administrative change. It would seem that the employer who pays wages by check showing thereon merely a statement of the deduction of the employee's tax from his wages will not be furnishing a proper form of tax receipt after the effective date of the amendment.

${ }^{95}$ Amendments to Subchapter C of Chapter 9 of the Internal Revenue Code, formerly Title IX of the Social Security Act.

${ }_{96} \S 614$ amending $\$ 1607$ (b) of the Internal Revenue Code, effective January I, I940. This amendment should result in a saving to employers as well as in considerable simplification of reporting procedures. This is the amendment to limit unemployment compensation taxes to the first $\$ 3, \infty \infty$ of annual wages. Such a limitation already exists in the case of old-age insurance and there are distinct advantages to providing a uniform tax base for both programs. It is estimated that this new limitation would result in a saving to employers of about $\$ 65,00$,000 a year. See S. Rep. 734, 76th Cong., Ist Sess. 27 (r939). 
the unemployment tax base the same as the tax base for old-age and survivors insurance. Thus wages "paid" during the calendar year, either actually or constructively, ${ }^{97}$ provide a definite tax basis upon which to determine the amount of the tax for that year independently of the year in which the services were performed. As a result, the necessity of estimating future, unascertained wages has been eliminated. ${ }^{98}$

2. Credits.-Credits extended to taxpayers against federal unemployment compensation taxes have been liberalized. Certifications for credit (up to the 90 percent limitation) for contributions actually paid under a state law are no longer limited to cases in which the state provisions comply with the federal law with respect to covered services performed in employment.99

It is no longer necessary, in order to receive credit against the tax, that the taxpayer pay the amount required by a state plan before the date of filing the federal return for the taxable year, since the amendments provide that full credit shall be allowed for contributions paid on, or before, the due date for the return. In the event payment of contributions is made after the due date, the taxpayer is now allowed 90 percent of the amount of the full credit to which he would have been entitled had he made such payment on or before the due date, provided payment is made on or before the June 30 which comes next after the due date of the federal return. ${ }^{\text {xoo }}$

In addition, the time for the allowance of credit against the employer's tax is made to extend from the June 30 next following the due date of the federal return to the succeeding June 30 , both dates inclusive, in cases

97 Constructive payment of wages is defined in Social Security Board Regulation No. 2, at page II, as follows:

"Wages may be either actually or constructively paid to the employee. Wages are constructively paid when they are credited to the account of or set apart for the employee so that they may be drawn upon by him at any time although not then actually reduced to possession. To constitute payment in such a case the wages must be credited or set apart to the employee without any substantial limitation or restriction as to the time or manner of payment or condition upon which payment is to be made, and must be made available to him so that they may be drawn at any time, and their receipt brought within his own control and disposition."

${ }_{98}$ Payments excluded from the definition of wages are the same under the provisions of Subchapter C, Chapter 9, Internal Revenue Code, as they are under Subchapter A, Chapter 9, Internal Revenue Code (discussed on page ro3 supra).

99 Old $\S$ I6or of the Internal Revenue Code allowed the taxpayer to credit against the tax the amount of contributions "with respect to employment" paid by him into an unemployment fund under a state law. The term "employment" meant employment as defined in the federal act. The amending section ( $\$ 609$ (a) (I)) omits the requirement "with respect to employment."

${ }^{\text {roo }} \S 609$ amending $\S$ I60I (a) of the Internal Revenue Code. 
where the assets of the taxpayer are in the custody or control of a court of competent jurisdiction or of a fiduciary appointed by such a court. ${ }^{\text {xor }}$

The amendments also take cognizance of those instances in which the taxpayer makes payment of contributions to the wrong state. Upon payment to the state entitled to contributions, the date of the erroneous payment is controlling for the purpose of allowing credit against the tax for the amount of contributions actually paid. If by reason of such other law the taxpayer was entitled to cease payment with respect to services under the law of the wrong state, and, by reason thereof, no contributions were paid by him to such state, federal credit based on contributions paid to the state entitled thereto is allowed against the tax as of the date on which the taxpayer filed his return for the taxable year. ${ }^{\text {102 }}$

3. Additional credits.-Amendments, with respect to credit in addition to the credit above discussed, condition the allowance of such additional credit upon certification of the state law by the board. In those cases in which the state law has lowered the rates of contributions in connection with services in employment not covered by the federal law, additional credit has been extended to the taxpayer. The additional credit allowed is computed by deducting the amount of contributions actually paid under the state law for the entire taxable year ${ }^{\mathrm{T} 03}$ from the amount the taxpayer would have been required to pay for the same period if he had been subject to the highest rate required by the state law, or if he had been subject to a rate of 2.7 percent, whichever rate is the lower. ${ }^{\text {104 }}$

The amendments have extended and clarified the conditions under which additional credit allowances shall be made. (I) In order that additional credit be allowed because of state law provisions reducing the rate of contributions, ${ }^{105}$ it is necessary that the board find, where such reductions are made in connection with a pooled fund or a partially pooled account, ${ }^{\text {,o6 }}$ that the basis of the employer's "experience with respect to

rox Note roo supra.

${ }^{102} \S 609$ adding subsection (4) to $\S \mathrm{I} 60 \mathrm{I}$ (a) of the Internal Revenue Code.

${ }^{103}$ The term "year" means any twelve consecutive calendar months. § 6ro amending $\S \mathrm{I} 602$ (c)(5).

${ }^{304} \S 609$ amending $\S \mathrm{x} 60 \mathrm{r}$ (b) of the Internal Revenue Code. It is thus apparent that additional credits will not be computed for periods less than one year.

ros $\$ 6$ Io (a) adding subsection (8) to $\S 1602$ (c) of the Internal Revenue Code.

"The term 'reduced rate' means a rate of contributions lower than the standard rate applicable under the State law, and the term 'standard rate' means the rate on the basis of which variations therefrom are computed."

ro6 "The term 'pooled fund' means an unemployment fund or any part thereof (other than a reserve account or a guaranteed employment account) into which the total contributions of persons contributing thereto are payable, in which all contributions are mingled and undivided, 
unemployment" or "other factors bearing a direct relation to unemployment risk" is not less than three consecutive years preceding the computation date. ${ }^{\mathrm{x} 7}$ (2) The lower rate, both with respect to contributions to guaranteed employment accounts and to reserve accounts, is permitted in those cases in which such accounts amount to a minimum of $2 \frac{1}{2}$ percent of the pay roll for three years preceding the computation date by which contributions to such accounts were measured. ${ }^{108}$

The amendments provide for the allowance of partial certification to the Secretary of the Treasury where a single state maintains more than one type of fund or account. Provisions are made for partial certification (I) where one of the funds fails to meet the conditions for additional credit allowance and (2) where a part of the reduced rate of contributions is payable into one fund or account, and part into another, and one of such reduced rates was allowable under state law provisions which do not meet the required state standards, the board's partial certification may allow only such reduced rates as are allowable under the state law whose provisions meet the required state standards. ${ }^{\text {xog }}$

and from which compensation is payable to all individuals eligible for compensation from such fund," $\$ 610$ (a) amending $\S 1602$ (c) (2) of the Internal Revenue Code.

"The term 'partially pooled account' means a part of an unemployment fund in which part of the fund all contributions thereto are mingled and undivided, and from which part of the fund compensation is payable only to individuals to whom compensation would be payable from a reserve account or from a guaranteed employment account but for the exhaustion or termination of such reserve account or of such guaranteed employment account," \$ 6IO and I602 (c) (3) of the Internal Revenue Code.

${ }^{x 07}$ ' The term 'computation date' means the date, occurring at least once in each calendar year and within twenty-seven weeks prior to the effective date of new rates of contributions, as of which such rates are computed," §6ro (a) amending $\S I 602$ (a) (x) of the Internal Revenue Code.

"No reduced rate of contributions to a pooled fund or to a partially pooled account, is permitted to a person (or group of persons) having individuals in his (or their) employ except on the basis of his (or their) experience with respect to unemployment or other factors bearing $a$ direct relation to unemployment risk during not less than the three consecutive years immediately preceding the computation date" (italics added), §6ro (a) adding subsection (7) to $\S 1602$ (c) of the Internal Revenue Code.

$\S 6$ Io amends $\S \mathrm{I} 602$ (a) (I) of the Internal Revenue Code, which latter section read as follows:

"Such lower rate, with respect to contributions to a pooled fund, is permitted on the basis of not less than three years of compensation experience."

$108 \S 6$ ro (a) amending $\S$ I602 (a) (2) (3), as to guaranteed employment accounts and separate reserve accounts. The amendment to $\S I 602$ (a) (3) as to separate reserve accounts does not become effective until January $I, x 942$. Prior thereto the old rate of $7 \frac{\pi}{2}$ percent as to such separate reserve accounts applies.

ro9 $\S 6$ IO (a) amending $\S$ I602 (b) (a) of the Internal Revenue Code. 
4. Extension of time for filing.-Beginning with the tax returns to be filed for the taxable year I939, the maximum extension of time for the filing of such returns under such rules and regulations as the Commissioner of Internal Revenue with the approval of the Secretary of the Treasury may prescribe, has been extended from sixty days to ninety days. ${ }^{\text {xo }}$

5. Coverage of services on United States land and services for United States instrumentalities. - The question whether employers for whom services are performed on land of the Federal Government may be liable for such contributions under the state law has been resolved in the affirmative. ${ }^{\text {III }}$

Further, the liability for contributions imposed by state law upon federal instrumentalities which are not wholly owned by the United States or which are not otherwise exempt, ${ }^{\mathrm{II} 2}$ has been definitely established so long as no discrimination is made against them and so long as certification of the state law has been made in accordance with the provisions of the Internal Revenue Code. In any taxable year if there is discrimination or, in the event proper certification of the state law has not been made by the board, the state law must provide for refund of the contributions paid for such year. ${ }^{\mathrm{Ix} 3}$

6. Services for state instrumentalities.-Services performed in employment for an instrumentality not wholly owned by one or more states or political subdivisions are no longer exempt from the federal unemployment compensation tax unless the instrumentality in question is immune from such tax under the Constitution of the United States. ${ }^{\text {Ir4 }}$

7. Coverage generally.-The provisions relating to coverage of services in employment under the Federal Unemployment Tax Act differ in several respects from the coverage provisions of Title II of the amendments. ${ }^{\prime \text { s }}$

rro $\S 612$ amending $\S 1604$ (b) of the Internal Revenue Code.

II $\S 6 \mathrm{I}_{3}$ amending $\S \mathrm{r} 606$ of the Internal Revenue Code.

Ixz Federal instrumentalities, not wholly owned by the United States or otherwise exempt under any other provision of law, include (x) national banks, (2) state banks which are members of the Federal Reserve System, (3) members of the Federal Home Loan Bank System, even though exempt under the provisions of the Home Owners Loan Act of I933 ( $\$ 909$ creates the exemption by amending section 5, Home Owners Loan Act, 48 Stat. r32 (r933), I2 U.S.C.A. \$ $\mathrm{I}_{4} 6_{4}\left(\mathrm{r}_{93} 6\right)$ ). Services performed in the employ of the United States Government and in the employ of federal instrumentalities wholly owned by the United States are exempt under the Federal Unemployment Insurance Tax Act.

${ }^{123} \S 6 \mathrm{I}_{3}$ amending $\S \mathrm{x} 606$ of the Internal Revenue Code. See also $\S 6 \mathrm{I}_{4}$ amending $\S \mathrm{I} 607$ (c) (6) of the Internal Revenue Code.

${ }^{1 \times 4} \S 6 \mathrm{I}_{4}$ amending $\S \mathrm{r607}$ (c) (6) of the Internal Revenue Code.

xx See discussion of included and excluded services for the same employer during a single day period, discussed page 99 supra. 
(I) Maritime service on American vessels, which service was specifically added by Title II to the general concept of those included employments covered by reason of their relationship to industry and commerce, continues to be excluded under the unemployment tax act. Service on foreign vessels is excluded employment under both the provisions of Title II amendments and the Federal Unemployment Tax Act; ${ }^{\text {:16 }}$ (2) contrary to the provisions of the Federal Unemployment Tax Act, however, Title II of the amendments excludes, in addition, service on certain fishing vessels of less than ten net tons unless performed "in connection with the catching or taking of salmon or halibut for commercial purposes"; and (3) the term employment, as defined in the tax act, excludes service in employment as an insurance agent or as an insurance solicitor if remuneration therefor is on a flat commission basis. ${ }^{\mathrm{IJ}}$. This exclusion is not found in the Title II provisions.

8. Tax is not a penalty. - The amendments have resolved a conflict in the holdings of bankruptcy referees and United States District Courts on the question whether the federal unemployment insurance tax is.a "penalty" under Section 57 of the National Bankruptcy Act, as amended, setting forth provisions for the proof and allowance of claims in bankruptcy. Specific provision is made that the full amount of the federal tax may be collected from a bankrupt estate which has not complied with the conditions prescribed by the law for obtaining 90 percent credit against the $\operatorname{tax}{ }^{x \times 8}$

\section{TITLE VII. GRANTS TO STATES FOR AID TO THE BIIND ${ }^{\text {II9 }}$}

The new law makes clear that aid to the blind is conditioned upon the need of the individual claimant, ${ }^{\mathbf{x} 0}$ and that any other income and resources he may have must be taken into consideration in determining such need. ${ }^{\mathrm{I2x}}$

${ }^{126} \S \S 6 I_{4}$ and $x 607$ (c) (4) of the Internal Revenue Code.

${ }^{\prime \prime 7} \S \S 6 r_{4}$ and $I_{607}$ (c) (r4) of the Internal Revenue Code.

rr8 $\S 902$ (i). $\S 57(J)$ of the National Bankruptcy Act, as amended, reads as follows:

"Debts owing to the United States or any State or subdivision thereof as a penalty or forfeiture shall not be allowed. . . .." On interpretation of the section see In re Royal Wilhelm Furniture Co., 23 F. Supp. 993 (Mich. I938); In re Hy-Grade Meat and Grocery Co., 26 F. Supp. 294 (N.J. I938); In re Standard Composition Co., 23 F. Supp. 39I (Mich. 1938); In re Lambertville Rubber Co., 27 F. Supp. 897 (N.J. I938); In re Illinois Art Industries, Inc., 27 F. Supp. 334 (Mich. 1939); In re Independent Automobile Forwarding Co., 28 F. Supp. 428 (N.Y. r939).

${ }^{x}$ Title $\mathrm{X}$ of the original Social Security Act.

${ }^{120} \S \S 702$ and 703 amending respectively $\$ \S 1003$ (a) and 1006 of the Social Security Act.

${ }^{22 x} \S$ 70r (b) amending $\S 1002$ (a) of the Social Security Act. $\S$ yOr (b) becomes effective on July $\mathrm{I}$, I94r. 
New provisions have been added relating (I) to personnel standards on a merit basis $;^{122}$ (2) to adjustment in the amount of the federal grant for the purpose of assuring the United States its pro rata share of amounts recovered by a state from a recipient, less funeral expenses paid by the state: $;^{\text {r23 } 3}$ and (3) to restriction of the use or disclosure of information concerning applicants and recipients. ${ }^{\mathbf{2 2}}$

Under the amendments a monthly expenditure of $\$ 20$ by the state with respect to each needy blind individual will be matched by the Federal Government, thus raising the possible maximum monthly payments to needy blind individuals from $\$ 30$ (under the original act) to $\$ 40 .{ }^{125}$

TITLE VIII. AMENDMENTS TO TITLE XI OF THE SOCIAL SECURITY ACT

The old definition of the term "state" has been expanded to include Puerto Rico when used in those titles of the original Social Security Act relating to grants to states for public welfare which include grants for maternal and child welfare, vocational rehabilitation, and public health. ${ }^{\mathrm{I26}}$

The amendments augment the general provisions contained in Title XI by adding two new sections. The first new section prohibits, under penalty, the disclosure of information in possession of the board except as prescribed by board regulations. The second new section provides a penalty for fraud (I) where false representations are made, with intent to defraud, concerning the provisions of the Social Security Amendments of I939, the Federal Insurance Contributions Act, the Federal Unemployment Tax Act, or of rules and regulations promulgated thereunder, and (2) where a person, (a) with intent to elicit specified types of information concerning any individual, falsely represents to the board that he is such individual (or the wife, parent, child, or duly authorized agent of such individual) for that purpose, or (b) "falsely represents to any person that he is an employee or agent of the United States." ${ }^{227}$

${ }_{222} \S 701$ (a) amending $\S 1002$ (a) of the Social Security Act. $\S$ 70I (a) becomes effective on January $x$, r940.

${ }_{223} \S 702$ amending $\S 1003$ (b) (2) of the Social Security Act.

224 Note I2I supra.

r25 $\S 702$ amending $\S 1003$ (a) of the Social Security Act.

${ }^{2} 6 \oint 801$ amending $\S$ I IOI (a) (r) of the Social Security Act.

$127 \S 802$. The provisions of Title $\mathrm{IX}$ of the amendments, which are miscellaneous, and affect various titles and sections of the Social Security Act, have been treated in the text or footnotes in connection with the discussion of those sections of the Social Security Act affected by them. 